\title{
Selection by Lot and Democracy: New Trend, Ancient Model
}

\author{
Ephraim David \\ University of Haifa, Haifa, Israel \\ Email: edavid@research.haifa.ac.il
}

How to cite this paper: David, E. (2021). Selection by Lot and Democracy: New Trend, Ancient Model. Advances in Historical Studies, 10, 7-20.

https://doi.org/10.4236/ahs.2021.101002

Received: January 12, 2021

Accepted: March 5, 2021

Published: March 8, 2021

Copyright $\odot 2021$ by author(s) and Scientific Research Publishing Inc. This work is licensed under the Creative Commons Attribution International License (CC BY 4.0).

http://creativecommons.org/licenses/by/4.0/

\begin{abstract}
Though considered the most democratic method of allocating citizens to office in Classical Greece, sortition (selection by lot) has never been adopted on a large scale by modern democracies (except for juries) and has fallen into oblivion. Recently, however, some political theorists, motivated by deep disappointment with current electoral practices, have been advocating a return to sortition without being sufficiently aware of the complexities involved in their ancient Athenian model. This study tries to explain the roots and ideology of sortition, the ways in which it operated in Athens and the causes of its functional success there for almost two centuries. Proposals of returning to a similar system should pay due attention to the significant role played by elections alongside the lottery in Classical Athens and the precautions taken there to prevent possible harm. In my view, the optimal formula for reform would be a political compromise combining, in one way or another, elections with sortition among volunteering candidates from various quarters of the civic society, selected in due proportions so as to be statistically representative of the demos. Selection by lottery should apply only to groups of people (e.g., committees and councils)—never to individual magistrates.
\end{abstract}

\section{Keywords}

Athens, Elections, Equality, Lottery, Recent Proposals

\section{Introduction}

In recent years, elections, considered for centuries as sacrosanct, the very cornerstone of democracy, have come under vehement attack in certain intellectual circles. Some political theorists and activists have proposed abolishing elections, whether partly or completely, in favor of sortition-a system which operated to a great extent in ancient Greek democracies and in some other historical contexts, such as a few city-states in Renaissance Italy. Later, sortition was endorsed by 
great philosophers, such as Jean-Jacques Rousseau and Montesquieu. ${ }^{1}$ In a recent paper, one of the enthusiastic supporters of lottery, Dimitri Courant, claims that "Sortition is the only selection procedure that is impartial, neutral and horizontal," preventing the need "to flatter an electorate, special interests or a party hierarchy to get reelected." Three years earlier, in defense of a genuine democracy and under the provocative title Against Elections, the Belgian cultural historian and political activist David Van Reybrouck advanced an overall attack on elections ("ballot-box fetishism"), proposed a return to the practice of sortition ${ }^{3}$ and received favorable reviews in some prestigious mainstream newspapers, such as The Times and The Observer.

Whatever their specific schemes, these proposals stem from a common background: disappointment with the functioning of our contemporary democracies, particularly when led by irresponsible and corrupt elites organized in political parties competing for power with the close assistance of tycoons and brainwashing experts; the extensive and systematic deception of the masses by populist politicians and their electoral propaganda, without any accountability. ${ }^{4}$

The proposals to make use of a lottery for allocating citizens to office frequently invoke the precedent of the Athenian democracy as a cherished model without being sufficiently aware of the complexities involved in that system ${ }^{5}$-its history, the details of its functioning, the reasons of its relative success (despite the harsh contemporary criticism it encountered in dissident circles) and particularly the importance of the dissimilarities in scale and substance between the Greek demokratia and modern democracy. On the other hand, studies in ancient Greek history frequently discuss the topic without referring to the recent trend of its imitation. ${ }^{6}$

The purpose of this paper is to reexamine the use of sortition in democratic Athens-by far the best documented classical paradigm - in an attempt to reflect ${ }^{1}$ See, e.g., Manin (1995): 19-108, with references to further literature.

${ }^{2}$ Courant (2019): 245 and passim contrasts sortition with other methods used to assign positions of power-elections, nomination, cooptation and certification; cf. Wright (2019): 39-45, who adds an anti-capitalist perspective to sortition. For earlier advocates of lottery selection, see Knag (1998); Carson and Martin (1999); Delannoi et al. (2011). For an extreme exponent see Guerrero (2014). See also next note.

${ }^{3}$ Van Reybrouck (2016) claims that we have become electoral fundamentalists, despising those elected but venerating elections; $c$. Sutherland (2018): 135-152, for a more moderate view. Burnheim (2016) adopted the neologism demarchy to designate a system based on a lottery selection for functional groups dealing with a single issue (or for small communities). Some scholars prefer the term "lottocracy" (in German "Lottokratie"). On the other hand, for a variety of electoral systems, see Norris (1997)

${ }^{4}$ See, e.g., Foa and Mounk (2015). The general elections in Israel in March 2020 and the forming of the subsequent government provide an excellent example of a systematic large-scale deception by electoral propaganda, with a total lack of accountability on behalf of those who had cynically "stolen" votes by what later proved to be bold mendacity.

${ }^{5}$ See the scholars cited in notes 1 and 2 above; cf. especially Bouricius (2013). For a critical approach of the attempt to use Athenian democracy as a model, particularly in recent American research, see Rhodes (2003): 45-69, with copious bibliography. To be sure, the Athenian model is invoked in a lesser degree, if at all, by those advocating sortition as a modest supplement to the collective decision-making method, not as its full replacement. See, e.g., Dienel (1999): 81-93; see also below and note 28 .

${ }^{6}$ See, e.g., Taylor (2007), with references to further literature. 
on the recent proposals for its revival and assess their prospects and limitations.

\section{The Ancient Model and Its Applicability}

Usually when we think about the differences between the ancient (Greek) democracy and modern democracy, the first aspect that comes to our mind is that the former was a direct democracy, while its modern version is representative. In classical demokratia the citizens themselves exercised their sovereignty by voting in the Assembly (ekklesia), whereas in modern democracy the citizens empower elected representatives to act in their name-with the rare exception of a referendum or plebiscite. An additional difference between ancient and modern democracy which may come to our mind is the separation of powers (executive, legislative and judiciary) - a principle believed to be essential to modern democracy but not applied in the ancient version, though its origins appear to be there-in various systems of checks and balances. Of course, many are aware of other topics as well, such as the extensive use of slaves, the absence of women's political rights and of universal rights in the ancient democracies. But, as mentioned above, one highly important aspect of classical democracy practically non-existent in the modern version of the regime-the use of sortition for allocating positions of power-is likely to be missed by many, perhaps most, people nowadays when asked to compare the two types of government. A monograph written about 120 years ago opened with these words:

There is no institution of ancient history which is so difficult of comprehension as that of electing officials by lot. We have ourselves no experience of the working of such a system; any proposal to introduce it now would appear so ludicrous that it requires some effort for us to believe that it ever did prevail in a civilized community. ${ }^{7}$

Despite recent arguments in favor of sortition and practical experiments on a modest scale with deliberative mini-assemblies (see below), I believe that this statement is liable to be still endorsed by a vast majority today. The few who advocate a return to sortition are aware that in sharp contrast with modern mentality, which for more than two centuries has regarded elections by vote as democratic par excellence, ancient Greek mentality regarded this method as oligarchic since it privileged citizens of a higher social status owing to their birth, education, skills, wealth, connections, etc. Sortition was the method considered in ancient Greece as truly egalitarian and therefore genuinely democratic. ${ }^{8}$ This was one of the factors which made the Athenian democracy an exception of Ro-

\footnotetext{
${ }^{7}$ Headlam (1891, repr. 1993): 1; cf. Glotz (1928): 223, who refers to the system as blatantly absurd: "une telle absurdité."

${ }^{8}$ Aristotle, Politics, 1294b 8-9. But later in the text (ibid. 1300a 33-34) the philosopher considers both methods of selection, by lot and by vote, as democratic provided that all citizens have an equal right to be elected. For elections as an aristocratic trait versus selection by lot as democratic, see also Isokrates, Panathenaikos, 153-154. Ancient sources are quoted throughout by the conventional method (prevalent in the research literature) that makes references easily accessible in all academic editions, with no need of further bibliographic data.
} 
bert Michels' "iron law of oligarchy," according to which regardless of its ideological façade, de facto every regime is an oligarchy. ${ }^{9}$

Long before becoming a method of selection for office, sortition had been used by the ancient Greeks as a fair device for other practical purposes, such as the division of land between brothers, the selection of settlers sent to found a new colony overseas and the initial distribution of land among them; hence the linguistic connection between sortition (klerosis) and a lot of land-kleros in Greek.

In ancient Athens the method was first used within a more complex system of selecting by lot from a group of previously elected candidates (klerosis ek prokriton) - a practice that presented a mixture between aristocratic, timocratic and democratic elements. If introduced by Solon's reforms (594 BC), as plausibly stated by the Aristotelian Athenian Constitution (8.1), ${ }^{10}$ it was abolished during the period of tyranny, which had started 34 years later, and then reinstalled in a significantly different form in the early stages of democracy (in $487 \mathrm{BC}$ ) ${ }^{11}{ }^{11}$ But after the offices were practically open to all citizens regardless of their wealth (with the abolition of Solon's timocratic rules) and pay for office was introduced (by mid-fifth century BC), the election of the archons and of most other officials was done by lottery. This inevitably led to diminishing the importance of the archons (until then the leading magistrates), while at the same time another office got the priority in the State, that of the ten generals (strategoi), elected each year by vote and entitled to be reelected (an interesting compromise of radical democracy). By the way, these strategoi were much more than military commanders since in the classical democracy, unlike the modern, there was no clear-cut separation between military and civilian spheres.

In the radical Athenian democracy, as in many other classical democracies, sortition was the predominant method of allocating citizens to positions of power. 600 of the annual 700 hundred officials were selected by lot and their reelection to the same office was forbidden; the nine archons and their secretary were the most prestigious among them. The 500 members of the Council (boule), who prepared the work of the decision-making body, the sovereign Assembly (ekklesia), were also selected by lot as representatives of their demes (villages or urban districts) in due proportions to their civic population, and re-election to the Council was allowed only for a second term but not in successive years. In addition, all the annual jurors (6000 dikastai) were selected by lot and were divided into courts, usually composed of 500 jurors, who always decided by secret ballot. Worth mentioning in this respect is the discovery of an archeological artefact-a pair of allotment-machines (kleroteria) for the selec-

${ }^{9}$ Michels (1915). For a convincing demonstration that this "law" of political sociology did not apply to the Athenian democracy, see Ober (1989).

${ }^{10}$ See Hansen (1991): 51 for a different opinion, based inter alia on Aristotle's Politics, 1273b 35-41; but for a convincing argument in defense of the method specified in the text, see Rhodes (1981): 146-148.

${ }^{11}$ [Aristotle], The Athenian Constitution, 22.5, with Rhodes (1981): 272-274. It is significant that under the tyranny offices were assigned either by means of election or by nomination, not by sortition. 
tion of jurors-exhibited in the Agora Museum at Athens. ${ }^{12}$ As a rule, the selection by lot was always made from those who presented themselves as candidates. In order to make such a system possible, by the mid-fifth century BC remuneration for serving in office was introduced in Athens, which enabled also the poor citizens to serve the State as magistrates. ${ }^{13}$ But pay for office would not have been sufficient to make such a vibrant, participatory democracy viable. A civic mentality of readiness to serve the State was no less important. The system could not have worked without a persistent mindset of involvement, usually absent in modern democracies, which suffer from an increasing apathy commonly known as the "democratic fatigue syndrome." From this viewpoint perhaps the most important institution of classical democracy was what the Athenians called " $h o$ boulomenos" - "he that is willing" [to be publicly active], the volunteer ${ }^{14}$ By way of association, one may recall the words of the herald addressing the Assembly: "Who wishes to speak?" The isegoria, i.e. the equal right of addressing the Assembly, the equality of [free] speech, was a major component of participatory democracy, even if in reality there were only a few leaders (frequently labelled by their enemies "demagogues") who had the charisma, the knowledge and the rhetoric abilities to persuade a large public audience time and again.

In one of his early dialogues Plato ascribes to his master, Socrates, an argument challenging the very foundation of the democratic system: when convened in their Assembly to decide about a project of shipbuilding or other technical matters, the Athenians were ready to listen only to experts, but when convened to decide about politics they were ready to listen to anyone who wished to speak-blacksmith or shoemaker, merchant or ship-owner, rich or poor, aristocrat or one of the commons. To which Socrates' interlocutor, Protagoras the sophist (and the eponymous hero of the dialogue), replies by appealing to the realm of instructive myth: unlike the professional or technical virtues that Zeus distributed only to specific sections of mankind, he decided to give a share in the political virtue (arête), based on the spirit of justice and decency, to all humankind. This, in Protagoras' view, justifies the attitude of the Athenians with respect to isegoria. ${ }^{15}$ It is the irony of political philosophy that one of the most important principles of democracy indirectly receives its support in a work of Plato, the philosopher usually identified with its committed enemies. The credo of Protagoras' speech on the capability of the average human being to have a share in politics-to judge, express his opinion and participate in the decision-making process-is the theoretical axiom of democracy, certainly of a participatory, deliberative democracy. This ideological premise does not claim that

\footnotetext{
${ }^{12}$ These can be easily recognized as such with the assistance of the Aristotelian Athenian Constitution, 64.2-3: see Rhodes (1984): 160-161, with commentary and illustrations.

${ }^{13}$ See, e.g, Stockton (1990): 103-116. In the Roman Republic there was no system of paying for office; the offices were called honores (honors without remuneration), which de facto imposed a timocratic limitation, excluding those who were not sufficiently rich. By the way, no public magistrate there was selected by sortition, all of them were elected by voting (or appointed to office).

${ }^{14} \mathrm{Cf}$. Hansen (1991): 71-72, 266-268.

${ }^{15}$ Plato, Protagoras, 319d, 322b-333a.
} 
that all human beings are equal; only that they have a common denominator which makes them capable and worthy of becoming actively involved in politics without any economic, educational or genetic prerequisites. ${ }^{16}$

Some historians tried to associate the method of selection by lot with religion: the results of sortition could be presented as expressing the will of the gods, not mere chance. ${ }^{17}$ At first glance this view may appear attractive; the origins of the system might have been somehow associated with religious beliefs, yet this theory receives no substantial support from our source-material: there is no specific evidence in ancient texts-either those supporting democracy or those of its opponents-for a religious rationale behind the lottery system.

Critics of ancient democracy always used selection by lot in order to attack the regime and even mock it. A locus classicus of such political dissent consists of a statement ascribed to Socrates by one of his accusers at his trial, as reproduced by Xenophon, another of Socrates' disciples, who fully shared his master's criticism on the matter, as made clear by the context:

But, said the accuser, he taught his companions to despise the established law by insisting on the folly of appointing public officials by lot, when none would choose a pilot or builder or flautist by lot, nor any other craftsman for work in which mistakes are far less disastrous than mistakes in statecraft. $^{18}$

Plato also shared this Socratic contempt towards the method of sortition. $\mathrm{He}$ sarcastically presented it as a preposterous trait of democracy devised to implement "a sort of equality for those who are equals and un-equals alike" (Republic, 557a). A similar judgment was echoed by Plato's disciple, Aristotle who, for all his criticism of his master's views, on this specific point agreed with him to a significant extent by presenting democratic equality as artificial, "arithmetic", in contrast with the proper equality-the "geometric", which applied only to those worthy of it. ${ }^{19}$ This is part of the general contempt typical of the ancient critics of democracy towards the intelligence of the average citizen and his capability for having a share in politics. Their voices are echoed by modern elitist theoreticians. $^{20}$

For an average modern audience, it may also appear aberrant in the extreme that the Athenians used a lottery to such an extent instead of electing officials according to their credentials and merits. However, strange as it may appear, ${ }^{16}$ Hansen (1991): 236 maintains: "The lot was based on the idea not that all men were equally expert, but that all men were expert enough at what they were chosen for..." I would say that in fact they did not need expertise for those offices (see below).

${ }^{17}$ This theory was first advanced by Coulanges (1864): 210-213; cf. Glotz (1928): 219-224.

${ }^{18}$ Memorabilia, 1.2.9, translation by Marchant (1923, repr. 1968).

${ }^{19}$ Politics, 1301b 29-39. On these two contrasting concepts of equality see Harvey (1965); Manin (1995): 58-61.

${ }^{20}$ Thus Megabyzos in Herodotus, Histories, 3.81; the Theban messenger in Euripides, Suppliant Women, lines 409-422. For a similar (elitist) approach in modern theoreticians see, e.g., Schumpeter (1976) and recently Brennan (2016), who advocates the foundation of an "epistocracy" (rule of experts) - a neologism awkwardly based on episteme ("knowledge" in Greek). In his view most voters are ignorant about politics and irrationally motivated- "hobbits" and "hooligans." 
this system was in practice in the Athenian democracy for almost two centuries, in the course of which Athens was not only a sovereign State but for a significant period also the leader of a maritime empire. Moreover, the system was in practice in additional democracies of the ancient world (including Syracuse in Sicily and Tarentum in South Italy) and, in one way or another, in certain cities in Renaissance Italy. ${ }^{21}$ Therefore, before ridiculing and rejecting it out of a patronizing attitude towards earlier civilizations, one has at least to make a serious attempt to understand what made it work.

Such an approach has to take into account a series of factors, many of which point, by the way, to the difficulties of applying a similar system to a modern State. The first factor is the very substance of most offices received by lottery. These were appropriate for performance by a person of average intelligence and in possession of some experience. The minimum age for office in ancient Athens was thirty, which means that by the time a citizen succeeded in being elected, he must have accumulated significant experience in public matters from his former participation (of over a decade) in the meetings, debates and the decision-making process of the Assembly (which met on an average of every ten days). By that time, he would also have gained a lot of experience at a local level from the political activities in his own deme (village or urban district). Most of these factors would not hold true in an attempt to apply sortition in a modern democracy, even at a local, municipal level, unless we were to modify drastically our whole political system, which is not that of a participatory democracy.

Moreover, although those who were selected by lot each year were new in their specific office, many among them would already have served in other State offices, and therefore were already equipped with a certain amount of experience in administration. Owing to the difference in scale between the polis and the modern State this asset would also hardly be valid in today's democracy, even if the whole system was to be significantly modified and made much more participatory.

Usually the magistrates acted in committees (mostly of ten members), and the risk that an individual might cause real harm was severely reduced by the qualifications and experience of his colleagues. This feature should be taken into account by any proposal of reinstating the method of sortition, which should apply only to groups, not to individual office-holders.

One should also remember that in Athens the lot was applied only to those who presented themselves as candidates and were interested in proving themselves worthy of office, a point which certainly deserves to be applied in any modern adaptation of the system. Before entering office in Athens a designate magistrate had to undergo a process of public scrutiny (dokimasia), which still made his rejection possible. This was mostly a brief formality, devised particularly to cope with the danger that persons suspected of oligarchic sympathies might be elected to office by mere chance. More important, there was no political immunity (in stark contrast to modern democracies): every magistrate was

\footnotetext{
${ }^{21}$ See Manin (1995): 63-93.
} 
accountable to the people, could be removed from office at any time by a popular vote, and by the end of his term of office had to give an account-especially of his handling of financial resources. This strict accountability was likely to deter citizens who did not feel themselves capable of undertaking the onus of serving in office. Notably, the notion of classical accountability has no parallel in modern democracies. This is a factor that can (and I believe, should) be modified in any attempt to reform the regime, even without applying sortition; a fortiori when trying to reinstate it.

As classical democracy was not based on professionalism, ${ }^{22}$ in certain cases the magistrates were assisted by a sort of "civil servants," usually public slaves or metics (free inhabitants without citizen status) in the service of the State, who had normally accumulated a lot of professional experience. If applied to modern democracy, such a system of experts would encounter the danger of creating a highly influential elite (like the British civil service). A similar risk would have been irrelevant in Athens owing to the non-civic status of those professionals. However, the most important factor in explaining the success of the Athenian system for such a long period is that the generals, all other military offices, certain financial offices and a few others which necessitated expert knowledge and special qualifications were allocated by elections (not by lottery), and re-election to those offices was allowed. The belief in the equality of opportunity did not make the Athenians go as far as to elect their military commanders by lot-and in Athens those "generals" were much more than military commanders; many of them were influential politicians. Despite the widespread use of sortition, Athenian democracy was far from being a dogmatic "lottocracy."

So far I have tried to explain why the system of sortition could work for so long in ancient Athens. As to the alleged foolishness of selecting a helmsman by lot (in the metaphor ascribed by Xenophon to Socrates' argument), one may argue that the extensive use of a lottery for selecting officials was not meant to make them helmsmen, but to keep the steering function to the demos. ${ }^{23}$ The method of sortition, coupled with the principle of annual terms of office, and the ban on reelection to most offices prevented the emergence of a bureaucracy, diminished the magistrates' power and helped to implement the equality of opportunity - at least the statistical chance of being selected to most offices. ${ }^{24} \mathrm{~A}$ high measure of rotation is essential to a participatory democracy, to the principle described by Aristotle as "to rule and be ruled in turns" (Politics, 1317b 19-21) which, owing to the difference in scale between the polis and the modern State, can hardly be genuinely revived but for a small section of the citizen-body. Coupled with regular participation in the Assembly, the high degree of rotation gave the citizens the feeling that the State belonged to them, that they were mas-

\footnotetext{
${ }^{22}$ But this holds true to a considerable extent also as far as many modern democracies are concerned. More than a century ago Faguet (1910) depicted the division of portfolios in the French government as the embodiment of a "cult of incompetence."

${ }^{23}$ See, e,g, Hansen (1991): 236.

${ }^{24} \mathrm{Cf}$. Ehrenberg and Hornblower (1996): 1426. For the mathematical chances of being selected by lot, see Manin (1995): 58-59.
} 
ters of their own fate. Moreover, they could be proud of the prestige associated with serving in office. Even after the political powers of the archons had diminished, the office still kept the aura of centuries (which holds true of some other institutions as well). Additional advantages of selection by lot were diminishing the amount of bribery and corruption, the emergence of cliques and the animosity or sedition-so often involved in electoral campaigns-contributing thereby to the promotion of social harmony. These assets are valid in principle with respect to modern attempts of reintroducing the system, whatever their specific details.

However, for all their vital interest in the promotion of social harmony, the Spartans, who defined themselves as "peers" (homoioi), had no office chosen by lot. All their offices were elective, and Aristotle clearly specified this as one of the criteria for considering Sparta as an oligarchy (Politics, 1294b 32-34). But in the work of his old age Plato, Aristotle's teacher, stated that the ephors, Sparta's most important magistrates, were chosen by a system "akin to selection by lot" (Laws, 692a). We may resolve this apparent contradiction by paying attention to another statement of Aristotle regarding the ephorate: the office was open to all citizens, with no discrimination whatsoever and, as a result, average citizens, with no special qualifications, succeeded in getting elected (Politics, 1270b 9-11, 27-29). This may explain Plato's reference to the system as one approximating a lottery: judging by the results of the elections, i.e. the competence of those elected, the system appeared to him similar to sortition which, mutatis mutandis, may somehow apply to the results of many recent elections as well-even in the case of high state officials.

Nevertheless, electoral disappointments and pitfalls in recent years should not lead us to the extreme solution of selecting prime ministers (or presidents) and senior members of the executive by lot. In my view elections for heads of State and the appointment of ministers by those elected, with the constitutional possibility of obstruction in liminal cases (to be defined by strict procedures), should continue to be the rule. However, in line with the Athenian system, those elected and nominated should be subject to strict rules of accountability to prevent (or at least minimalize) the damages of misrule and corruption.

As mentioned above, ancient democracy did not operate on a principle of separation of powers: e.g. most of the legislative functions were fulfilled by the Assembly and the People's Courts, but the Council of 500 had also a significant part in the process (while it had also executive and judicial powers). In modern times so far the system of sortition has been applied mostly in the cases of juries (e.g., in the United Kingdom and the USA), owing to what is viewed as the fairness of being judged by "peers"-average fellow-citizens. Some critics underline many flaws of the jury system-inter alia lack of professionalism, frequent errors of judgment, emotional motivation and irrational verdicts. ${ }^{25}$ But other systems have their flaws as well. In a book on the Athenian democracy David Stockton ${ }^{25}$ See, e.g., Vidmar and Hans (2007). 
aptly observed:

Throughout most of human history, those members of any society who lacked both wealth and influence... have regularly found it difficult, if not impossible, to secure justice... because those who interpreted and administered the laws were safeguarding (consciously or instinctively) the interests of their own kind. ${ }^{26}$

For the purpose of this study it is sufficient to regard the application of sortition to juries as a proof of its practicability on a large scale, provided it is properly assisted by professional experts. The jury system may serve to strengthen the practicability of sortition in other domains as well with respect to groups of average people who should be able to reach a sensible decision in political matters after proper deliberation. Some recent experiments in British Columbia, Iceland and Ireland with randomly selected groups (deliberative mini-assemblies) convened to discuss and propose constitutional changes also support the practicability of the system. ${ }^{27}$ Usually, the promoters of these and similar experiments with randomly selected groups deliberating over one central issue, do not invoke the Athenian democracy as their main source of inspiration, since their basic aim is to provide a limited supplement to the prevalent method of collective decision-making, ${ }^{28}$ not to replace it by another system. However, the ancient paradigm becomes far more relevant when dealing with parliaments, the embodiment of legislative power, and with the possibility to select their members by lot.

Different proposals have recently been advanced in this respect, but their common ideological denominator, at least of the more radical among them, is the axiomatic belief that randomly selected citizens would significantly improve the decision-making process through deliberation. It is argued that this would be a fairer form of representation than the elective alternative and that a reasonable number of citizens would be ready to get involved in politics. ${ }^{29}$ But one is left to wonder inter alia, particularly in view of the difficulty of changing prevalent mentalities, whether the demos would give up completely its power of choice and regard those selected by lottery as their genuine and legitimate representatives $^{30}$ though, one may argue, on the other hand, that in many electoral systems the lists of candidates are far from being representative. They are frequently made through appointment by a party leader or through primaries-elections by a party central council, a sort of mini-assembly, i.e. either by monarchic or by semi-oligarchic procedures. project of "policy juries" with a narrow mandate, advanced through the Jefferson Center (after having been theoretically advocated in his doctoral dissertation in political science at the University of Minnesota in 1973).

${ }^{29}$ To encourage a large number of candidates, Zakaras (2010): 455-471 proposed doubling the medium salary as remuneration for the service of those selected by lot.

${ }^{30} \mathrm{For}$ an empirical investigation of the support for sortition among the average citizens and the political elites see Jacquet et al. (2020).
} 
As to the method of implementation, I would opt for one of the more pragmatic proposals, such as that of a bicameral parliament composed by one chamber to be elected by vote (in the spirit of party-politics), the other to be drawn by lottery from volunteering candidates-members of various sections of the civic society selected in due proportions so as to be statistically representative (similarly to a polling procedure) and endowed inter alia with powers of obstruction. The two categories may also work together, within a mixed legislative body, not a bicameral one. Once the principle is adopted, there are several possibilities to be taken into consideration, but the application details are superfluous to our argument. ${ }^{31}$

All in all, a multidisciplinary research team including economists, sociologists and physicists concluded that an addition of a parliamentary section of members selected by lot and not associated with political parties could significantly improve the parliamentary system. ${ }^{32}$ Under such a reform, democracy might have a better chance to become once more really deliberative, vibrant-unlike its present, fossilized state, in which parliamentary debates have become strikingly artificial and ornamental, almost meaningless, since their results are practically known in advance (owing to party-lines and coalitions). The adoption of sortition among volunteers (in one way or another) for the legislative, in addition to elections, is liable to galvanize participatory democracy and significantly reduce (or, at least, balance) the extent of the ills involved in an exclusively elective system, particularly the manipulation of party elites, the extensive cheating of voters by deceptive electoral propaganda, the manipulation of populist politicians and the over-influence of wealthy oligarchs and tycoons in politics-the blatantly plutocratic aspect of most modern democracies. The optimal ways of reaching those aims remain to be further explored not only for macro-politics but also with respect to other forms of administration.

In our universities, for instance, there is a plethora of committees, such as the executive committee of the Senate, the appointments and promotion committee, the disciplinary and didactic committees. At this point I will indulge in a personal reminiscence. Many years ago I proposed to introduce selection by lottery (instead of by voting) among faculty members for the Senate and for most of the above committees - not for the functions of department chair, deans, rector and president which, I believe, should remain elective-as positions of academic leadership. Within this "laboratory" experience, it was both sad and amusing to see the reactions of my colleagues: some considered the proposal as sheer madness and accused me of "populist levity," a reaction which could show the degree of their distrust in their average colleagues, their "peers"-otherwise entrusted with teaching and evaluating students. One may suspect that the proposal was viewed as a serious threat to academic oligarchy-the rule of the few who were in a po-

${ }^{31}$ Bouricius (2013) proposed a complex model of legislation based on several allotted bodies. For various alternatives cf. Van Reybrouck (2016); Fishkin (2019): 75-100; Gastil and Wright (2019): 3-38.

${ }^{32}$ See Pluchino et al. (2011). 
sition to manipulate elections (and re-election) in their own interest. In this case, a basic argument against lottery-the possible ignorance and irrationality of randomly selected persons-hopefully had no relevance. Getting a fair representation (statistically speaking) of faculties, schools and departments, as well as other problems such a system might encounter, could easily be solved by laying down preliminary rules (e.g., selecting to the appointments and promotion committee only from the rank of full professors). A semi-direct democracy already operates to a certain extent in many universities by means of faculty meetings, at which all have an equal right to speak and to vote. Why then copy the elective political system of representative democracy, with all its defects and pathologies, instead of aspiring to install a healthier system wherever applicable?

\section{Conclusion}

Though considered the most democratic form of selection for office in Classical Greece, sortition has never been adopted on a large scale by modern democracies (with the exception of juries) and has fallen into oblivion. In the course of more than two centuries, since the foundation of the USA and the French Revolution, elections have been regarded as sacrosanct and quintessential to democracy. Recently, however, as a result of the acute crisis of contemporary democracies, some political theorists have been advocating a return to sortition without being sufficiently aware of the complexities involved in the system as practiced by the Athenian democracy and the precautions taken there to prevent possible harm. Those proposing the adoption of a similar system today should pay due attention to the differences in scale and substance between the polis and the modern State, and abandon the utopian idea of abolishing the suffrage altogether, which would mean replacing "ballot-box fetishism" by lottery fetishism. In line with the Athenian experience, I would prefer a moderate method: combining, in one way or another, elections with lottery from volunteers belonging to various quarters of the civic society - selected in due proportions so as to be statistically representative of the demos. In my view, sortition should apply only to groups of people (councils, committees, mini-assemblies) - never to individual magistrates of any significance, i.e. positions of leadership.

This theoretical framework of a "mixed constitution"-a proportionate blend between "aristocratic"/meritocratic and democratic/aleatory elements-is a formula worthy of further theoretical elaboration and empirical trials. Such a system could be appropriate not only for polities but also for other types of organizations, including academic institutions. However, a return to sortition should not be taken as a panacea for the pathology of contemporary democracies; it can only serve as a significant component of a more complex treatment.

\section{Acknowledgements}

I would like to thank Professor Brian Martin for his extremely useful comments on my paper. 


\section{Conflicts of Interest}

The author declares no conflicts of interest regarding the publication of this paper.

\section{References}

Bouricius, T. (2013). Democracy through Multi-Body Sortition: Athenian Lessons for the Modern Day. Journal of Public Deliberation, 9, Article 11. https://doi.org/10.16997/jdd.156

Brennan, J. (2016). Against Democracy. Princeton, NJ: Princeton University Press.

Burnheim, J. (2016). The Demarchy Manifesto. London: Academic Press.

Carson, L., \& Martin, B. (1999). Random Selection in Politics. London: Praeger Westport. Coulanges, F. De (1864). La cité antique. Paris: Librairie Hachette.

Courant, D. (2019). Sortition and Democratic Principles: A Comparative Analysis. In J. Gastil, \& E. O. Wright (Eds.), Legislature by Lot... (See Below) (pp. 229-248). New York: Verso Books.

Delannoi, G., Dowlen, O., \& Stone, P. (2011). The Lottery as a Democratic Institution. Dublin: Policy Institute, SciencesPo.

Dienel, P. C. (1999). Planning Cells: The German Experience. In U. Khan (Ed.), Participation beyond the Ballot Box (pp. 81-93). London: University College Press.

Ehrenberg, V., \& Hornblower, S. (1996). Sortition. In S. Hornblower, \& A. Spawforth (Eds.), Oxford Classical Dictionary (p. 1426). Oxford: University Press.

Faguet, E. (1910). Le culte de l'incompétence. Paris: Éditions Coda.

Fishkin, J. S. (2019). Random Assemblies for Lawmaking: Prospects and Limits. In J. Gasil, \& E. O. Wright (Eds.), Legislature by Lot... (See Below) (pp. 75-100). New York: Verso Books.

Foa, R., \& Mounk, Y. (2015). Across the Globe, a Growing Disillusionment with Democracy. New York Times, 15 September.

Gastil, J., \& Wright, E. O. (2019). Legislature by Lot: Transformative Designs for Deliberative Governance. New York: Verso Books.

Glotz, G. (1928). La cité grecque. Paris: Éditions Albin Michel. https://doi.org/10.2307/1838560

Guerrero, A. (2014). Forget Voting-It's Time to Start Choosing Our Leaders by Lottery. Aeon, 23 January.

Hansen, M. H. (1991). The Athenian Democracy in the Age of Demosthenes. Oxford: Blackwell.

Harvey, F. D. (1965). Two Kinds of Equality. Classica et Medievalia, 26, 101-146.

Headlam, J. W. (1891, repr. 1933). Election by Lot at Athens. Cambridge: Cambridge University Press.

Jacquet, V., Niessen, C., \& Reuchamps, M. (2020). Sortition, Its Advocates and Its Critics: An Empirical Analysis of Citizens' and MPs' Support for Random Selection as a Democratic Reform Proposal. International Political Science Review. https://doi.org/10.1177/0192512120949958

Knag, S. (1998). Let's Toss for It: A Surprising Curb on Political Greed. The Independent Review, 3, 199-209.

Manin, B. (1995). Principes du gouvernement représentatif. Paris: Calmann-Lévy. 
Marchant, E. C. (1923, repr. 1968). Xenophon, Vol. IV Memorabilia and Oeconomicus. Cambridge, MA: Harvard University Press.

Michels, R. (1915). Political Parties: A Sociological Study of the Oligarchical Tendencies of Modern Democracy. London: Jarrold.

Norris, P. (1997). Choosing Electoral Systems: Proportional, Majoritarian and Mixed Systems. International Political Science Review, 18, 297-312. https://doi.org/10.1177/019251297018003005

Ober, J. (1989). Mass and Elite in Democratic Athens. Princeton, NJ: Princeton University Press. https://doi.org/10.1515/9781400820511

Pluchino, A., Garofallo, C., Rapisarda, A. et al. (2011). Accidental Politicians: How Randomly Selected Legislators Can Improve Parliament Efficiency. Physica A, 390, 3944-3954. https://doi.org/10.1016/j.physa.2011.06.028

Rhodes, P. J. (1981). A Commentary on the Aristotelian Athenaion Politeia. Oxford: Oxford University Press.

Rhodes, P. J. (1984). Aristotle, the Athenian Constitution. Translated with Introduction and Notes. Harmondsworth: Penguin Books.

Rhodes, P. J. (2003). Ancient Democracy and Modern Ideology. London: Duckworth.

Schumpeter, J. A. (1942, repr. 1976). Capitalism, Socialism, and Democracy. New York: Harper and Brothers.

Sintomer, Y. (2019). From Deliberative to Radical Democracy? Sortition and Politics in the Twenty-First Century. Participations, 11, Article 23.

Stockton, D. (1990). The Classical Athenian Democracy. Oxford and New York: Oxford University Press.

Sutherland, K. (2018). The Triumph of Election: A Pyrrhic Victory. Rivista di Storia delle Idee, 7, 135-152.

Taylor, C. (2007). The Sociology of Election and Lot in the Athenian Democracy. Hesperia, 76, 323-345. https://doi.org/10.2972/hesp.76.2.323

Van Reybrouck, D. (2016). Against Elections: The Case for Democracy. London: Random House.

Vidmar, N., \& Hans, V. P. (2007). American Juries: The Verdict. Amherst, NY: Prometheus Books.

Wright, E. O. (2019). The Anti-Capitalist Argument for Sortation. In J. Gastil, \& E. O. Wright (Eds.), Legislature by Lot... (See Above) (pp. 39-45). New York: Verso Books.

Zakaras, A. (2010). Lot and Democratic Representation: A Modest Proposal. Constellations, 17, 455-471. https://doi.org/10.1111/j.1467-8675.2010.00608.x 